
Acta Universitatis Nicolai Copernici • Pedagogika XXXII/2016

Nauki Humanistyczno-Społeczne • Zeszyt 435

DOI: http://dx.doi.org/10.12775/AUNC_PED.2016.001

Stanisław Chrobak

UKSW w Warszawie

\section{ZAUFANIE JAKO FUNDAMENT PODEJMOWANIA DZIALAŃ EDUKACYJNYCH}

Dedagogicznej refleksji od początku towarzyszy przeświadczenie, _ że wychowanie jest sztuką i wymaga szczególnego rodzaju wrażliwości, innowacyjności działań oraz twórczego zaangażowania. Poszukując odpowiedzi na pytanie, co jest istotą wychowania, mamy na uwadze nie tylko wiedzę teoretyczną o tym fenomenie, zawierającą jego uzasadnienie czysto zewnętrzne, tkwiące w określonych poglądach, doktrynach, podejściach czy stanowiskach, ale i sferę praktyczną, jego codzienny wymiar, wpisujący się w dzieje i biografie jednostek ludzkich, pokoleń, kultur i społeczeństw. Człowiek udoskonala się bowiem nie tylko przez zdobywanie abstrakcyjnej wiedzy o prawdzie, ale także przez żywą relację z drugim człowiekiem, która wyraża się przez dar z siebie i przez wierność. Poznanie oparte na wierze, którego podstawą jest zaufanie między osobami, nie jest pozbawione odniesienia do prawdy: wierząc, człowiek zawierza prawdzie, którą ukazuje mu druga osoba. Każda sytuacja wychowawcza jest więc doświadczana w horyzoncie przestrzeni obecności człowieka oraz czasu, przede wszystkim czasu dorastania dziecka. Poznanie tej sytuacji i oddziaływanie na nią jest podstawowym warunkiem dobrego, tj. skutecznego wychowania. Tytułowe sformułowanie jest zatem próbą refleksji nad wartością zaufania w dynamice ludzkiej egzystencji i w praktyce 
edukacyjnej. Pedagogika twórczego współbycia wyrasta z edukacyjnej wspólnoty i zarazem ją buduje. Zatem dla wychowawcy każda chwila jest inna, jak inna jest każda osoba oraz sytuacja jej życia. Właściwy sens zaufania dotyczy sytuacji, w których rozmaite okoliczności zmuszają nas do wyrażenia swoich przekonań w praktyce, do zaangażowania się w działaniu.

\section{Pojęcie i wartość zaufania}

Zaufanie (ang. trust, fr. confiance, niem. das Vertrauen, ros. dawierie) opisywane bywa w kategoriach wartości, uczuć, potrzeb, ludzkich postaw, a także cechy, stanu umysłu oraz jako podstawowy warunek edukacji i dialogu. Pojęcie to można rozumieć jako wiarę w szczerość ludzkich intencji i może być wyjaśniane (omawiane) z perspektywy filozoficznej, socjologicznej, psychologicznej, teologicznej czy pedagogicznej. W naukach pedagogicznych zaufanie nabiera szczególnego znaczenia, dotyczy bowiem rzeczywistości wychowawczej, swoistej przestrzeni międzyludzkiej, w obrębie której dokonuje się wewnętrzne wzrastanie młodego człowieka1. W pewnych sytuacjach ludzie decydują się obdarzyć kogoś zaufaniem, w innych się od tego powstrzymują. Podstawą zaufania są zatem pozytywne intencje innego podmiotu, a realizuje się ono w regularnych, uczciwych, pozostających w zgodzie $\mathrm{z}$ normami i nastawionych na współpracę z innymi ludźmi. Abyśmy ufali, potrzebna jest nam wiedza na temat wiarygodności innych ludzi, ale także wiedza, jak działa cały system społecznych norm, reguł zachowania i oczekiwań. W tym też kontekście Piotr Sztompka stwierdza, że „zaufanie jest zakładem podejmowanym na temat niepewnych, przyszłych działań innych ludzi. W tym rozumieniu na zaufanie składają się dwa elementy: przekonania i ich wyrażenie w praktyce" ${ }^{\prime 2}$.

1 Por. J. Michalik-Surówka, Zaufanie, w: Encyklopedia pedagogiczna XXI wieku, t. VII, pod red. T. Pilcha, Warszawa 2008, s. 823-831; A. Ohler, Zaufanie, w: Praktyczny słownik biblijny, pod red. A. Grabner-Haider, Warszawa 1995, kol. 1472-1473; K. Geryn, Zaufanie, w: Encyklopedia katolicka, t. 20, Lublin 2014, kol. 1271-1272.

2 P. Sztompka, Zaufanie. Fundament społeczeństwa, Kraków 2007, s. 69-70. 
Zaufanie odgrywa w życiu społecznym niebagatelną rolę i nie brak myślicieli i badaczy, którzy sądzą, że życie społeczne bez zaufania byłoby po prostu niemożliwe. Z wysokim stopniem zaufania społecznego wiąże się zatem współpracę między ludźmi, stabilność społeczeństwa, a nawet jego dobrobyt. Nie każdy rodzaj zaufania do takiej sytuacji prowadzi. Zaufanie zatem może funkcjonować na trzech poziomach, przy czym nie wszystkie $\mathrm{z}$ tych poziomów będą jednakowo interesować wszystkich tych, którzy są zainteresowani społecznym rozwojem:

- między ludźmi w parze,

- między człowiekiem a konkretną grupą społeczną (przyjaciółmi, rodziną, współpracownikami),

- między człowiekiem a kimś zupełnie mu obcym.

Ostatni poziom zaufania jest najważniejszy z punktu widzenia społecznego, ponieważ jest pomostem łączącym różne społeczne światy, wiodącym ku wspólnemu dobru ${ }^{3}$. Darzenie innych osób zaufaniem pociąga za sobą pozytywne działania wobec tych osób - wyrażenie zaufania $\mathrm{w}$ działaniu. Zaufanie wzmacnia więzi między jednostką a wspólnotą, wpływa na poczucie tożsamości, skłania ludzi do współpracy. „Wzajemne zaufanie we wspólnocie jest tym silniejsze, im bardziej wspólne, podzielane przez wszystkich, są podstawowe wartości. [...]. Tymczasem przemieszanie się wartości, stylów życia, mód, gustów, zwyczajów i obyczajów, idei i ideologii w skali globalnej prowadzi do pluralizmu aksjologicznego, relatywizmu etycznego i anomii"4.

Kryteria wykorzystane przy podjęciu decyzji o zaufaniu nie eliminują ryzyka. Zaufanie wymaga, aby się miało świadomość realnej sytuacji każdej osoby. Dopóki zaufanie rozpatrujemy wyłącznie jako relację z innymi osobami, obdarzanie zaufaniem opiera się na ocenie ich wiarygodności. Zaufanie pokładane w drugim człowieku jako osobie zakłada, iż człowieka należy ujmować jako podmiot otwarty, ukierunkowany intencjonalnie, realizujący się poprzez spełnianie wartości. Odnosi się nie tylko do poziomu moralnego, ale do całościowego rozwoju człowieka jako osoby. Zaufanie to najpierw powierzenie się

3 Por. T. Szlendak, Zaufanie, w: Fundamenty dobrego społeczeństwa. Wartości, pod red. M. Bogunia-Borowskiej, Kraków 2015, s. 332-333.

4 P. Sztompka, Zaufanie..., s. 386. 
w jakimś aspekcie „dobrej woli” drugiego. Mieć zaufanie do dobrej woli to wierzyć, że drugi człowiek nie chce nas zdradzić, okłamać. Że zechce nam pomóc, gdy będziemy tego potrzebowali ${ }^{5}$. „Zaufanie jest oddaniem się do dyspozycji drugiego, powierzeniem mu swej nadziei. Nie powierzałbym nadziei komuś, do kogo nie miałbym zaufania, nie okazywałbym rozporządzalności komuś, o kim z góry wiem, że czyha na jej wykorzystanie. Ufając oddaję w jego ręce nie tylko moje nadzieje, ale i całego siebie, mając pewność, że nie zostanę wykorzystany, że drugi nie potraktuje mnie w kategoriach podmiotowo-przedmioto-

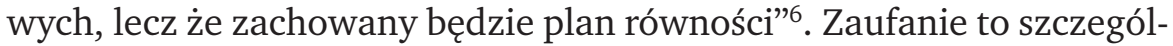
ny, ludzki pomost do niepewnego, przyszłego świata, w którym centralną rolę odgrywają inni ludzie. Wiąże się z wyrażeniem przekonań w działaniu. „Zaufanie interpersonalne kształtuje się w toku wymiany informacji, komunikatów niewerbalnych, wymiany uczuć i ustosunkowań. Cechuje się dynamiką wartościowania korzyści i strat. Korzyści to poczucie bycia rozumianym, poprawa samopoczucia, wzrost wiedzy i obniżenie trudności [...]. Zaufanie interpersonalne uwarunkowane jest interakcją cech osoby pomagającej i wspomaganej. Osoba wzbudzająca zaufanie ma duży potencjał empatii, jest spostrzegana jako kompetentna i zapewnia osobie wspomaganej autonomię i szacunek"7.

Zdobywanie zaufania wymaga wielkiej cierpliwości, skromności, wrażliwości i polega na stworzeniu atmosfery do wysłuchiwania poglądów innych osób i ich ofert czy przyswajania wiedzy o innych i refleksyjnego uzewnętrzniania tychże informacji. W tym kontekście należy doprowadzić do tego, by podmioty weń zaangażowane zauważyły siebie i otworzyły się na siebie. Jest to warunek wstępny swobodnej wymiany różnych poglądów, przekonań, odczuć, wyobrażeń, mitów, stereotypów. Nie chodzi tu wyłącznie o sytuację, w której osoba obdarzana zaufaniem zachowuje się w sposób wiarygodny, po prostu

5 Por. M.Z. Stepulak, Zaufanie jako czynnik osobowego rozwoju człowieka, w: Studia z psychologii rozwoju, pod red. J. Makselona, Kraków 2002, s. 169-174; K. Tarnowski, Ustyszeć niewidzialne. Zarys filozofii wiary, Kraków 2005, s. 53-54.

6 J. Bukowski, Zarys filozofii spotkania, Kraków 1987, s. 252-253.

7 J.C. Czabała, H. Sęk, Pomoc psychologiczna, w: Psychologia. Podręcznik akademicki, t. 3, red. nauk. J. Strelau, Gdańsk 2000, s. 606. 
spełnia oczekiwania partnera, ale w której odwzajemnia mu się zaufaniem, oczekując godnego zaufania zachowania od partnera i to on tym razem jest zobowiązany do spełnienia pokładanych w nim oczekiwań, jeżeli relacja ma być kontynuowana ${ }^{8}$. „Człowiek - stwierdza Jan Paweł II - udoskonala się bowiem nie tylko przez zdobywanie abstrakcyjnej wiedzy o prawdzie, ale także przez żywą relację z drugim człowiekiem, która wyraża się przez dar z siebie i przez wierność. W tej wierności, która uzdalnia do złożenia siebie w darze, człowiek znajduje pełnię pewności i bezpieczeństwa. Zarazem jednak poznanie oparte na wierze, którego podstawą jest zaufanie między osobami, nie jest pozbawione odniesienia do prawdy: wierząc, człowiek zawierza prawdzie, którą ukazuje mu druga osoba" " Zaufanie to przekonanie oraz oparte na nim działanie. Każdy z partnerów jednocześnie obdarza zaufaniem i jest nim obdarzany.

\section{Zaufanie w dynamice ludzkiej egzystencji}

Człowiek nie może być sobą, nie otwierając się na to, co od niego inne, szczególnie na innych ludzi. „Osoba - stwierdza E. Mounier - istnieje tylko zwracając się ku drugiemu człowiekowi, tylko poprzez drugiego człowieka może siebie poznać, tylko w drugim człowieku może siebie odnaleźć. Pierwotnym doświadczeniem osoby jest doświadczenie drugiej osoby. [...] można by niemal powiedzieć, że istnieję jedynie $\mathrm{w}$ takim stopniu, w jakim istnieję dla kogoś drugiego, względnie: być - znaczy kochać"10. Dla każdego człowieka prawda o nim samym, sensie i celu jego życia oraz otaczającym go świecie rzeczy i ludzi jest niezbędna w procesie jego osobowego rozwoju i dorastania do pełni człowieczeństwa. Człowiek odnajduje w swym „ja” powiązanie z „ty” oraz $\mathrm{z}$ „my”. Doświadczenie osoby ludzkiej nie zamyka się w doświadczeniu swojego „ja”, lecz nastawione jest na egzystencję innych osób. Toż-

8 Por. Z. Jasiński, Zaufanie w pedagogice Janusza Korczaka, w: Korczakowskie dialogi, pod red. J. Bińczyckiej, Warszawa 1999, s. 102-104.

9 Jan Paweł II, Encyklika Fides et ratio, (Rzym 14.09.1998), n. 32.

10 E. Mounier, Wprowadzenie do egzystencjalizmów, przeł. A. Bukowski, Warszawa 1964, s. 37. 
samość rozwijającej się osoby jest rozpięta między możliwością siebie i sobą realnym. Utożsamiając się ze wszystkimi innymi ludźmi, odnajduje to, co stanowi centrum jego samego. „Podstawowym doświadczeniem osobowym - pisał J. Tischner - i zarazem warunkiem możliwości genezy konstytutywnej Ja w jego «byciu-sobą» jest doświadczenie innego. Doświadczenie to ma dwie strony: ja jestem «inny niż inni», «inni są inni niż ja». Jestem «dla nich» zupełnie «inny», jestem «osobny», jestem «obcy». [...] Chodzimy «obok siebie», żyjemy «obok siebie», w pewnej chwili znikamy i już nas nie ma «obok siebie»"11.

Analiza dynamizmu ludzkiego bytu wskazuje na jego nieskończone i niczym nieograniczone perspektywy. Prawda o człowieku jest wielowymiarowa, ciągle nie do końca rozpoznana. Człowiek jako istota zdolna do refleksywnego samopoznania odczytuje swą potencjalność oraz konieczność i sposoby jej aktualizowania. W tym dynamicznym charakterze ludzkiego bytu zaufanie wskazuje na współuczestniczenie w sposób odpowiedzialny w tworzeniu nowej rzeczywistości. Ta rzeczywistość skłania do stawiania coraz to nowych pytań. „Zaufanie zakłada z jednej strony jakby «przerzucenie» siebie czy «niepamiętanie» o sobie w relacji do kogoś albo - w granicznym przypadku - czegoś, która staje się w zaufaniu relacją bezpośredniq̨ i w tym sensie uczestniczącą. [...] Z drugiej wszakże strony, zaufanie udzielane jest coraz bardziej przez podmiotowe centrum, centrum wolne, to znaczy takie, które zaufania może, ale nie musi udzielić, które zdolne jest także do namysłu i decyzji, czy «warto» i «należy» komuś (czy czemuś) zaufać. To z kolei zakłada podmiot «osobny», niezastępowalny i nie do końca komunikowalny, a przede wszystkim obdarzony - jak mówił Levinas «psychizmem», jawny dla siebie i dlatego także zdolny do bycia swoistym centrum, z którego wypływa zaufanie. Podmiot ten jest zarazem «przenikalny» na otoczenie, odnajdujący się od razu wewnątrz pola oddziaływań, niejako na ich przecięciu, tak że często ku niemu skierowane są intencje drugich i że jest od początku konfrontowany ze światem drugich i przez nich kwestionowany - musi się z nimi «liczyć»"12.

11 J. Tischner, Spór o istnienie człowieka, Kraków 1998, s. 221.

12 K. Tarnowski, Usłyszeć niewidzialne. Zarys filozofii wiary, Kraków 2005, s. 163. 
Osoba jest więc zawsze jakoś odrębna, odosobniona zarówno wobec innych bytów, jak i innych osób. Natura człowieka wyznacza cel życia i jego rozwoju. Zatem „tożsamość osobowa powinna objąć zrozumienie siebie jako istoty cielesno-psychiczno-duchowej, która może każdą swą decyzją budować w sobie dobro - a tym samym budować siebie jako osobę. W tym sensie każdy człowiek całe swe życie jest twórcą. [...]. Tożsamość osobowa obejmuje również świadomość możliwości lepszego rozumienia innych i siebie dzięki poznawaniu form, jakie powstały w efekcie poszukiwania wartości i dążenia do wartości wiązanych z prawdą o człowieku i świecie w różnych miejscach oraz w różnym czasie, składając się na tożsamość kulturową"13. W tym kontekście człowiek wciąż „wychyla się” ku przyszłości, do czegoś dąży, akceptuje wszystkie swe, traktowane integralnie, osobowe wymiary oraz konieczność i możliwość świadomego ich włączenia w budowanie siebie jako osoby.

Dynamika - potencjalność ludzkiego życia, ogarniająca wszystkie aspekty realne całej ludzkiej bytowości, stanowi istotny wymiar tego życia. „Skoro chcemy dowiedzieć się - pisze E. Fromm - co znaczy być człowiekiem, musimy być przygotowani na znalezienie odpowiedzi nie w sensie różnorodnych możliwości człowieka, lecz samych warunków ludzkiego istnienia, z których wyłaniają się owe możliwości jako potencjalne rozwiązania"14. Wielostronny dynamizm osoby mający u swej podstawy rozumną naturę a bezpośrednio oparty na zdolności wyboru i działania sprawia, że osoba wciąż się rozwija, przekształca środowisko i jest twórcą nowych wartości. Osoba zatem jest tego rodzaju bytem, który jest sobą metafizycznie od „samego początku”, ale jednocześnie staje się, realizuje, kontynuuje, rozwija, tematyzuje niejako nieskończoność. Wnikając w rzeczywistość wyraża siebie, samopoznaje, uświadamia się, odkrywa, rozjaśnia, doświadcza, weryfikuje. Przez te wszystkie akty i działania świat staje się na swój sposób wewnątrzosobowy, a jednocześnie osoba się uzewnętrznia i obiektywizuje. Dokonująca się nieustannie na przestrzeni całego ludzkiego

13 K. Olbrycht, Prawda, dobro i piękno w wychowaniu człowieka jako osoby, Katowice 2000, s. 190-191.

14 E. Fromm, Rewolucja nadziei, Poznań 2000, s. 87. 
życia aktualizacja wszystkich właściwych człowiekowi potencjalności swoje wypełnienie znajduje dopiero w momencie jego śmierci. Osoba ludzka jest otwarta na nieskończoność i transcendencję. Cały sens tak zwanego doczesnego życia ludzkiego wtedy tylko zyskuje wartość, gdy to wszystko, co człowiek czyni teraz, jest tylko zapoczątkowaniem „pełni” i spełnienia się ludzkiej osoby w jej aktach osobowych ${ }^{15}$. Fakt ludzkiego poznania i wynikającego zeń działania ukazuje się w podwójnym wymiarze: materialnym i duchowym. Zaufanie ma w tym poznaniu charakter konkretny, mieści się bowiem w określonym kontekście społeczno-kulturowym i jest przez ten kontekst modelowane. W atmosferze zaufania okazuję drugiemu człowiekowi swoją twarz, ufam mu. Zaufanie jest niezwykle naturalną i wspaniale realizującą osobowy charakter bytu ludzkiego postawą względem innych ludzi. Człowiek jest bytem rzuconym w świat i nie tyle chodzi o to, by dzięki ludziom i poprzez ludzi zdołał się w tym świecie „właściwie urządzić”, ile o to, by doskonalił siebie i innych. Choć wielokrotnie człowiek może się spotkać z brakiem zaufania i z wykorzystaniem swej otwartości przez innych, to jednak zawsze tkwić w nim będzie potrzeba zawierzenia siebie bliźnim, dokonująca się w postawie zaufania ${ }^{16}$. „Dość często uważa się, że ufność jest cechą osobowości. Gotowość do okazania zaufania wynika z systemowej struktury osobowości"17.

Osoba nie może się rozwinąć i zrealizować swych potencjalności bez współdziałania z innymi osobami, zespołem innych osób komunikujących się we „wspólnym dobru” i stanowiących z tego powodu jakieś „my”. Mówiąc o wspólnotowym wymiarze życia człowieka, podkreśla się nie tyle socjologiczny fakt, iż ludzie są ze sobą w jakiś sposób razem i są od siebie na różne sposoby zależni, ile raczej akcentuje wewnętrzny charakter więzi, które tych ludzi łączą ze sobą. Prawdziwa wspólnota ludzka jest tam, gdzie osoba odnajduje siebie poprzez dar z siebie i zdolność przyjęcia daru drugiego człowieka. Człowiek formułuje w niej doniosłe cele, których osiąganie powoduje zmiany spo-

15 Por. M.A. Krąpiec, Człowiek w kulturze, Lublin 1999, s. 62-73.

16 Por. J. Bukowski, dz. cyt., s. 263-264.

17 P. Sztompka, Zaufanie..., s. 217. 
łeczne i polityczne ${ }^{18}$. Ważne $\mathrm{w}$ tym kontekście staje się takie kształtowanie relacji międzyludzkich i całego życia społecznego, aby ludzie mogli czuć się bezpieczni, by rosło pomiędzy nimi zaufanie, a w sytuacjach zagrożeń i niepowodzeń osobistych mogli liczyć na pomoc ze strony innych. „Żadne wolne społeczeństwo nie przetrwa długo [...] bez trwałych tradycji moralnych i konwencji społecznych. Alternatywą dla takich norm będzie nie indywidualność i autonomia, lecz przymus i patologie społeczne. Takie relacje określam - stwierdza Piotr Sztompka - jako moralne, a za najważniejsze ich odmiany uważam zaufanie, lojalność, wzajemność, solidarność, szacunek i sprawiedliwość. Owe sześć relacji elementarnych to swoisty budulec relacji bardziej złożonych"19. Uniwersalne wartości ludzkie istnieją i muszą być podkreślane jako siła wszelkiego rozwoju i postępu. To w człowieku należy poszukiwać norm życia społecznego. Człowiek „godny zaufania” jest pewną wartością. Zaufanie staje się niezbędną strategią postępowania w zetknięciu z nieprzejrzystością otoczenia społecznego. Bez zaufania bylibyśmy sparaliżowani i niezdolni do działania. Aby wybrać spośród możliwych dróg postępowania, musimy często uciekać się do zaufania. „Mówiąc o kimś, że jest człowiekiem godnym zaufania, że potrafi wytrwać na stanowisku i nie zdradzić, wyrażamy pochwałę wysokiej klasy. Takiemu człowiekowi można powierzyć trudne rzeczy do zrealizowania, on potrafi je wykonać nie tylko w tym sensie, że jest dosta-

18 Por. J. Tischner, Spór o istnienie człowieka, s. 219.

19 P. Sztompka, Kapitał społeczny. Teoria przestrzeni międzyludzkiej, Kraków 2016, s. 150.

„Wspólnota ludzka wspiera się na wartościach. Te zaś powinny być niezmienne i niezależne od społecznych kontekstów. Wartości społecznych się nie negocjuje. Nie można ich naciągać jak gumę do żucia. Nie można być trochę uczciwym lub czasami lojalnym. Albo się jest uczciwym i lojalnym, albo nie. [...] Wartości nadają sens każdemu obszarowi i aspektowi życia ludzkiego. Niezliczone działania, decyzje i wybory, jakie ludzie codziennie podejmują, zależą od wartości, które za nimi stoją. To wartości nadają sens i znaczenie ludzkim działaniom, zachowaniom i wyborom. Wartości są fundamentami życia społecznego. Wartości są filarami zarówno jednostkowego, jak i wspólnotowego życia człowieka". M. Bogunia-Borowska, Życie w dobrym społeczeństwie. Wartości jako fundament dobrego społeczeństwa, w: Fundamenty dobrego społeczeństwa. Wartości, pod red. M. Bogunia-Borowskiej, Kraków 2015, s. 22-23. 
tecznie sprawny zawodowo. Robotnikowi godnemu zaufania można powierzyć jakąś robotę, on jej nie spartaczy, bo wie jak to wykonać, tu jednak chodzi o coś znacznie więcej [...], o zachowanie pewnej postawy w sytuacjach trudnych dla danej jednostki"20. Zaufanie do ludzi niesie ze sobą nadzieję na moralne przekształcanie świata.

Szukanie pewności w zaufaniu pokładanym w Bogu i Jego Słowie stanowi istotę postawy człowieka wierzącego. Już starotestamentowy lud Boży żył w świadomości i ufności, że Bóg jest z nim, że zna jego drogi i że te drogi są właściwe. To zawierzenie pozwalało ludziom Starego Testamentu mieć wielkie zaufanie do rzeczywistości (np. Abraham czerpie zaufanie z doświadczenia, że Bóg nie opuścił go w czasie jego wędrówek i dotrzymywał słowa; wierzący Hiob w obliczu nieszczęść z pełnym zaufaniem i wewnętrznym spokojem oczekuje dalszych wypadków). Zawierzenie to staje się w pełni możliwe w wyznaniu: Jezus Chrystus umarł za świat, w Nim Bóg oddał się ostatecznie swojemu stworzeniu, w Nim Bóg jest obecny dla ludzi. Stwórca troszczy się o swoje stworzenia (por. Mt 6, 25-32). Zaufanie polega nie na pewności wyjścia w taki lub inny sposób przy pomocy Boga $\mathrm{z}$ beznadziejnej sytuacji, lecz na żywej świadomości, że człowiek, który pozostaje wierny Bogu, może zdać się na obecność Boga nawet wtedy, gdy wydaje się, że Bóg jest daleko ${ }^{21}$. „Okazanie zaufania Bogu i przylgnięcie do prawd Objawionych przez Niego nie jest przeciwne ani wolności, ani rozumowi ludzkiemu. Już w relacjach międzyludzkich nie jest przeciwna naszej godności wiara w to, co inne osoby mówią nam o sobie i swoich zamierzeniach oraz zaufanie ich obietnicom (na przykład, gdy mężczyzna i kobieta zawierają małżeństwo), aby wejść w ten sposób we wzajemną komunię. Jeszcze mniej sprzeczne $\mathrm{z}$ naszą godnością jest więc «okazywanie przez wiarę pełnego poddania naszego rozumu i naszej woli objawiającemu się Bogu» i wejście w ten sposób w wewnętrzną komunię z Nim"22. Wiara jako zaufanie jest sposobem

20 R. Ingarden, Wykłady z etyki, Warszawa 1989, s. 249.

21 Por. A. Ohler, dz. cyt., kol. 1472-1473; A. Grabner-Haider, Zawierzenie, w: Praktyczny słownik biblijny, pod red. A. Grabner-Haider, Warszawa 1995, kol. 1473.

22 Katechizm Kościoła Katolickiego, Poznań 1994, n. 154. 
bycia, „światłem na drodze”. Źródłem zaufania do Boga nie jest zatem jedynie słowo, ale fenomen „wierności samego Boga”, który umożliwia zaufanie.

\section{Zaufanie w praktyce edukacyjnej}

Strategia wychowania oparta na zaufaniu uczy dziecko zaufania i współdziałania. Wychowanie jako działanie i zarazem jako jego doznawanie jest jednością zapodmiotowioną w wymiarze tego, co jest specyficznie ludzkie między osobami. Człowiek, pozostając w coś zaangażowanym, daje siebie w zastaw sprawie, która go pochłania, nie tracąc jednak przy tym zdolności oglądu całej sytuacji. W każdej sytuacji wychowawczej jest doświadczenie obecności człowieka. „Wychowawca poznaje: 1) dziecko, 2) sytuację, jako obiektywne uwarunkowania, 3) dziecko w sytuacji wychowawczej, 4) siebie w sytuacji wychowawczej. [...]. Ale na samym początku, zarysowując warunki poznania sytuacji wychowawczej - poza świadomością, odpowiedzialnością i zmianą nastawienia - trzeba sobie z całą pokorą uprzytomnić tajemnicę człowieka i jego osobowego «Ja»"23. Tak rozumiana sytuacja wychowawcza sama w sobie jest wartością, ponieważ łączy ludzi we wspólnym realizowaniu wartości, jaką jest ich człowieczeństwo - poznawane, kształtowane i realizowane zarówno przez wychowanka, jak i przez wychowawcę. O jej specyfice decyduje fakt, że wychowawca bierze na siebie odpowiedzialność za wychowanka i za siebie w tej relacji, za jej zgodność z zasadniczym celem wychowania i wynikającymi z niego wartościami. Sytuacja wychowawcza oparta na relacji wychowawczej jest sytuacją wspólnego doświadczenia łączącego uczestniczące w niej osoby, doświadczenia zorientowanego na dobro budowania człowieczeństwa ${ }^{24}$. Zatem ,zaufanie do siebie i zaufanie do drugiego są korelatywne i nawzajem się pobudzają: zaufanie do drugiego może

23 K. Ablewicz, Teoretyczne i metodologiczne podstawy pedagogiki antropologicznej. Studium sytuacji wychowawczej, Kraków 2003, s. 202-203.

24 Por. K. Olbrycht, O utracie zaufania do wychowania, „Horyzonty wychowania" 2015, Vol. 14, No 31, s. 106-107. 
wyzwolić zaufanie do siebie, a to z kolei może pomóc w obdarzaniu nim kogoś innego. W ten sposób rodzi się wzajemność" 25 .

Wiedza o tym, jaka jest istota człowieka i jego człowieczeństwa była i jest podstawą wiedzy o tym, jak wychowywać człowieka. Problematyka wychowawcza zatem dotyczy zawsze konkretnego człowieka. Wychowawca stwarza i proponuje mniej lub bardziej korzystne warunki rozwoju osoby i rozwój ten bezpośrednio umożliwia. Rola wychowawcy polega na udostępnianiu, przybliżaniu podmiotowi, który posiada swą autonomię, szeregu wartości stanowiących trwały dorobek społeczności. Treści, które są przekazywane w procesie wychowania, powinny wprowadzać wychowanka w całość dorobku ludzkiej kultury z zachowaniem i ukazaniem hierarchii dóbr kulturalnych. Współczesny wychowawca powinien ponadto umieć uważnie odczytywać „znaki czasu”, czyli dostrzegać pojawiające się wartości, które pociągają młodzież. Wychowawca wychowując doświadcza działającej podmiotowości wychowanka. Osoba bowiem doskonali się przez uczestnictwo, które jest aktywnością, otwarciem dwustronnym: odbiorem i dawaniem. Zatem budowanie siebie w swoim człowieczeństwie daje nadzieję, ale i wymaga nadziei. Jest to nadzieja, która może się tlić nawet wówczas, gdy wszystkie inne zostaną unicestwione ${ }^{26}$. „Nie jest prawdą, że szacunek dla wolnego wyboru ucznia oznacza brak jakiejkolwiek propozycji typu aksjologicznego. Bez ukazania świata wartości nie ma prawdziwego wychowania. Nie jest też prawdą, że trzeba odmienne, niekiedy przeciwstawne, systemy wartości przedstawiać tak, jakby wszystkie były jednakowo ważne i możliwe do przyjęcia. Nauczyciel jawi się wówczas jako ktoś, kto nie ma własnych poglądów i przekonań, a więc nie zasługuje na wiarygodność i zaufanie"27. Najpierw więc nauczyciel-wychowawca sam musi odkryć siebie, praw-

25 K. Tarnowski, Usłyszeć niewidzialne..., s. 168.

26 Por. J. Maritain, Dynamika wychowania, tłum. A. Ziernicki, „Znak” 1991, nr 436(9), s. 28-29; A. Murawska, Edukacja jako troska o nadzieję człowieka, Szczecin 2008, s. 316-320.

27 J. Nagórny, Posłannictwo szkoły - posłannictwo nauczyciela, „Cywilizacja. O nauce, moralności, sztuce i religii” 2005, nr 14, s. 22. 
dę i wartości, by potem móc zaprosić ucznia-wychowanka do wejścia w dialog z wartościami, które chce mu zaproponować.

Uczniowie zafascynowani osobowością dobrego nauczyciela widzą w nim godny naśladowania wzór i przejmują w konsekwencji wiele jego pozytywnych cech. I odwrotnie: nauczyciel mało ambitny, niepodatny na innowacje, hołdujący rutynie, nie pobudzi uczniów do intensywnego wysiłku, nie zachęci ich do „wyjścia poza przeciętność”, nie roztoczy przed nimi celów, o których urzeczywistnienie warto zabiegać. Zatem decydującą rolę w pracy nauczyciela odgrywać będzie aspekt osobowych relacji między nim a uczniem (wychowankiem). W relacji tej manifestuje się cała osobowość nauczyciela. „Istnieje tylko jeden sposób dotarcia do ucznia - jak pisał Martin Buber - zdobyć jego zaufanie. Dla przestraszonego niepewnością świata nastolatka zaufanie oznacza oswabadzające przeświadczenie o istnieniu ludzkiej prawdy, prawdy ludzkiej egzystencji. Gdy zaufanie ucznia zostało już zdobyte, jego opór przeciwko wychowaniu ustępuje miejsca niezwykłemu zdarzeniu: akceptuje nauczyciela jako osobę. Czuje, że może mu zawierzyć, że wychowawca nie traktuje go jako przedmiotu, lecz bierze udział w jego życiu, że zaafirmował go, zanim zapragnął wywierać na niego wpływ"28. Relacja ta w filozofii J. Tischnera nazwana została powiernictwem nadziei. Wychowawca jako powiernik nadziei staje się dla wychowanka oparciem, które ma charakter nie tylko emocjonalny, ale przede wszystkim egzystencjalny. „Wierność - pisał J. Tischner - wyłania się z odkrycia prostego faktu: że ja i ty, wychowawca i wychowanek, jedziemy na tym samym wozie. Nikt nie stoi na dachu. Nasz wóz jest wspólny. Jeśli wóz się rozleci, jeśli nasza nadzieja okaże się złudna, wszyscy się potłuczemy. Wszyscy, niemniej... Wierny wychowawca wie jednak, że jego tragedia musi być większa. Wierny wychowawca to wychowawca, który godzi się nieść taki ciężar na swych barkach. [...]. Wychowawca musi ryzykować sobą. W krainie kłamstwa jego prawdomówność musi być większa niż prawdomówność wychowanka. W krainie niesprawiedliwości jego sprawiedliwość musi przewyższać poczucie sprawiedliwości jego wychowanków.

28 M. Buber, Kształcenie charakteru, „Znak” 1968, nr 169-170 (7-8), s. 917 (915-926). 
W krainie nienawiści i podejrzliwości on musi być bardziej prosty i jawny. Na tym polega jego wierność. Ten, kto powierzył mu swą nadzieję, musi wiedzieć, że powiernik jest razem z nim - razem, to znaczy, że w sprawach podstawowych o pół kroku przed nim"29.

Po obu stronach procesu pedagogicznego - pisał Janusz Tarnowski - stoją przede wszystkim nie tyle wychowawca i wychowanek, co raczej ludzie, czyli człowiek wobec człowieka. Istotnym momentem pedagogicznym jest obustronny kontakt międzyludzki. Jeśli otwieramy swoje „wnętrze” przed partnerem, ujawniamy nasze najgłębsze przeświadczenia, intymne uczucia, wprowadzając niejako $\mathrm{w}$ „tajniki naszego ja", to mamy do czynienia z dialogiem personalnym. Jego warunkiem i wartością, na której się opiera, jest wolność. Dialog egzystencjalny natomiast wyraża się nie tylko słowami, lecz całą osobą, oddaniem swego ,ja” do dyspozycji partnera, aż do poświęcenia własnego życia. Wartością właściwą dla tej formy dialogu jest miłość. Jest rzeczą oczywistą, że uwarunkowania każdej z tych form są inne: do dialogu rzeczowego wystarczy, by partnerzy mieli kompetencję w danym zakresie, dialog personalny zakłada zaufanie wzajemne, do prowadzenia zaś dialogu egzystencjalnego konieczne jest zupełne wyrzeczenie się samego siebie, całkowite przezwyciężenie samolubstwa i egocentryzmu ${ }^{30}$. „Do tego właśnie celu - stwierdza Janusz Tarnowski - pomocne są treści zawarte w egzystencjalizmie: oparcie się na «rdzeniu» istoty ludzkiej, czyli na jej najgłębszym «ja», oraz na zastosowaniu dla celów pedagogicznych kategorii typu egzystencjalnego: autentyczności, dialogu, spotkania i zaangażowania"31.

Można także mówić o zdobywaniu zaufania w miłości. Miłość często rodzi się w długim procesie budowania zaufania, a nie wybucha $\mathrm{w}$ jednej chwili, przytłumiając wszystkie inne emocje. Zaufanie w odwzajemnionej miłości wyklucza zazdrość. Relacja ta buduje tzw. wspólnotę miłości. „Ty jest dla mnie wołaniem, TY mnie wzywa, bo cierpi, szuka, błądzi, boi się lub przeciwnie - jest szczęśliwy, rado-

29 J. Tischner, Etyka solidarności, Kraków 2000, s. 91.

30 Por. J. Tarnowski, Człowiek - dialog - wychowanie. Zarys chrześcijańskiej pedagogiki personalno-egzystencjalnej, „Znak” 1991, nr 436(9), s. 69-74.

31 J. Tarnowski, Jak wychowywać?, Warszawa 1993, s. 90. 
sny, obdarowany. Jeśli odpowiadam na to wezwanie, to staję się odpowiedzialnym za TY. TY obdarza mnie zaufaniem, a ufać komuś - to czuć się bezpiecznym, osłoniętym, chronionym a nie zaryzykowanym. Relacja JA - TY ontologicznie oznacza więc caritas międzyludzką"32. W tym też kontekście twórca systemu prewencyjnego, ksiądz Jan Bosko, był przekonany, że wychowawcy mogą wywrzeć na swych podopiecznych dużo większy wpływ wychowawczy, gdy przemawiają do nich „głosem serca” i „upominają z dobrocią”, niż wtedy na przykład, gdy stosują wobec nich kary czy - inaczej mówiąc - traktują ich instrumentalnie. System prewencyjny polega na tym - stwierdza Jan Bosko - „że podwładnych zaznajamia się z przepisami i regulaminem zakładu, a następnie roztacza się nad nimi taką opiekę, że wychowankowie znajdują się zawsze pod czujnym okiem dyrektora lub asystentów, którzy jako kochający ojcowie przemawiają do nich, w każdej okoliczności służą im za przewodników, udzielają rad i upominają z dobrocią [...]. Wychowawca, pozyskawszy sobie raz zaufanie wychowanka, będzie mógł wywierać na niego wielki wpływ: doradzać mu, upominać i strofować"33. Oznacza to wchodzenie osób w relację i wzajemne doświadczenie siebie i prowadzi do odkrywania w każdym wychowanku istoty rozumnej, wolnej i odpowiedzialnej, wrażliwej na dobro, prawdę i piękno, zdolnej do autorefleksji, samorealizacji i twórczości, a także - niejednokrotnie - transcendencji. Umiejętność akceptowania wychowanków, rozumienia empatycznego, umiejętność bycia autentycznym, kongruentnym, otwartym, bezpośrednim prowadzi do powstawania wspólnej przestrzeni „pomiędzy” partnerami dialogu. Zatem „zaufanie rozumowi prowadzi wychowawcę do oparcia całej swojej pracy na założeniu, że chłopiec jest w stanie pojąć, docenić i w sposób wolny przyjąć propozycję wychowawczą, kiedy zmierza ona do jego prawdziwego dobra. Wymaga ona, aby rozmawiać z nim w sposób uczciwy, nie dawać mu do zrozumienia, iż traktuje się go niepoważnie, próbując jedynie pozyskać jego przekonanie i wolną zgodę. Wszystkie te formy

32 M. Sawicki, Dziecko jest osoba. Szkice z teorii kształcenia i wychowania, Warszawa 1995, s. 25.

33 J. Bosko, System prewencyjny w wychowaniu młodziė̇y, w: Współczesny wychowawca w stylu księdza Bosko, pod red. J. Wilka, Lublin 1998, s. 214-215. 
oszustwa są na dłuższą metę nieskuteczne, co więcej, powodują utratę jakiegokolwiek zaufania do wychowawcy i wywołują podstawowy brak zaufania w stosunku do każdego działania wychowawczego. Rozum oznacza więc zaufanie do dialogu"34.

Z podobną formą zaufania mamy do czynienia w relacji Mistrz-uczeń. „Mistrz to ktoś, za kim chcemy podążać, kto nas fascynuje, pociąga, inspiruje. Mistrz jest potrzebny wówczas, gdy samemu nie daje się rady, gdy albo brak odwagi, albo jeszcze umiejętności, aby kroczyć samodzielnie. W swoim uczeniu się człowiek potrzebuje mistrzów, czyli osób, które może naśladować po to, aby następnie zrobić daną rzecz samodzielnie" 35 . Uczeń dobrowolnie wybiera osobę mistrza i pragnie pójść za nim, naśladować go. Zafascynowany osobowością mistrza ufa w słuszność jego działań, wynikających z przyjęcia określonego systemu wartości. Opisana relacja jest ze strony ucznia stosunkiem bezgranicznego zaufania i niezłomnej wiary w człowieka, w wartość osoby ludzkiej. Ze strony mistrza jest natomiast zaufanie do ucznia, że okaże się on godnym człowiekiem, rzeczywistym i godnym realizatorem wartości, które mistrz pragnął mu swym przykładem wskazać ${ }^{36}$. W zaufaniu mieszczą się elementy ryzyka i niepewności. „Tym, co daje uczniowi mistrz, jest poznanie, świadomość ja, odwaga stawiania trudnych pytań (kim jestem?; dokąd zmierzam?). Mówiąc językiem współczesnej psychologii, mistrz wyposaża ucznia w podstawy tożsamości. [...] Wskazywanie drogi przez mistrza nie ma charakteru instrumentalnego, nie jest zawładaniem, wyobcowywaniem czy manipulowaniem osobą wychowanka, ucznia"37. Odwaga i bezkompromisowość w re-

34 G. Gatti, Zawód: wychowawca chrześcijański, Warszawa 1997, s. 26-27.

35 T. Bauman, Mistrzowie i szkoły myślenia w uniwersytecie, w: Gdańskie rodowody pedagogiczne. Geneza, kontynuacje, inspiracje, przemieszczenia znaczeń wychowawczych, pod red. E. Rodziewicz, K. Rzedzickiej, E. Zalewskiej, Gdańsk 2004, s. 73.

36 J. Bukowski, dz. cyt., s. 257-264.

37 M. Karkowska, Literackie obrazy uczeń - mistrz w wychowaniu, w: Idee pedagogiki filozoficznej, pod red. S. Sztobryna, B. Śliwerskiego, Łódź 2003, s. 142.

„Tym, co pociąga wychowanka - stwierdza Tadeusz Gadacz - są wartości; nazwałem to na własny użytek wspólną wędrówką wychowawcy i wychowanka ku horyzontowi prawdy, dobra i piękna. Wędrówką, w której nie tylko wychowaw- 
alizacji wysokich wartości bez oglądania się na opinię i na ewentualne życiowe porażki pociąga ucznia, który widzi w osobie mistrza dzielnego etycznie człowieka, dla którego słuszność moralna znaczy więcej, niż cokolwiek innego w porządku codziennego życia. I choć nauczyciele (uczniowie) spotykają się wielokrotnie z brakiem zaufania i wykorzystywaniem swojej otwartości przez innych, to jednak dzięki potrzebie i postawie zaufania mogą doskonalić siebie i innych. „Człowiek - podkreślał J.W. Dawid - wychodzi poza siebie, troszczy się, bezinteresownie czyni coś dla drugiego; jest to miłość dusz, bo przedmiotem jej jest wewnętrzna, duchowa treść człowieka, jego dobro moralne, jego oświecenie i udoskonalenie jako istoty duchowej. Dla nauczyciela z takim powołaniem każdy nowy uczeń to jakby rozszerzenie i przyrost własnej jego jaźni, to nowe zadanie do spełnienia w zakresie jego własnego osobistego życia"38.

Strategia wychowania oparta na zaufaniu uczy dziecko zaufania i współdziałania, odwołuje się do dobrze pojmowanej miłości do dziecka i przekonaniu o bogactwie jego osobowości. „Dziecko jest istotą rozumną - pisał Janusz Korczak - zna dobrze potrzeby, trudności i przeszkody swego życia. Nie despotyczny nakaz, narzucone rygory i nieufna kontrola, ale taktowne porozumienie, wiara w doświadczenie, współpraca i współżycie. [...] Ma dziecko przyszłość, ale ma i przeszłość: pamiętne zdarzenia, wiele godzin najistotniejszych rozważań. Nie inaczej, niż my, pamięta i zapomina, ceni i lekceważy, logicznie rozumuje - i błądzi, gdy nie wie. Rozważnie ufa i wątpi" ${ }^{39}$. Zaufanie w koncepcji pedagogicznej Korczaka nie jest li tylko teoretyczną kategorią, ale wyrasta z pedagogii zweryfikowanej w codziennej praktyce, w różnych placówkach i na różnych terenach. Swoją koncepcję sza-

ca prowadzi wychowanka, ale także dzięki wychowankowi sam może zbliżyć się do prawdy, dobra i piękna. Wtedy wychowanie nie jest tylko programem, ale i żywą rzeczywistością, która dokonuje się we wspólnocie osobowej, we wspólnocie między mistrzem i uczniem". Wychowanie na rozdrożu. Dyskusja redakcyjna, „Znak” 1991, nr 436(9), s. 51.

38 J.W. Dawid, O duszy nauczycielstwa, Warszawa 1948, s. 9.

39 J. Korczak, Prawo dziecka do szacunku, w: Źródła do dziejów wychowania i myśli pedagogicznej, t. III, wyboru dokonał i oprac. S. Wołoszyn, Warszawa 1966, s. 135. 
cunku dla dziecka buduje on na zasadzie zaufania. Sądzi, że wychowankowi można i należy ufać, że wychowawca może być godny zaufania. Fakt powierzenia przez dziecko tajemnicy swojemu wychowawcy może być dla niego najwyższą nagrodą, najlepszym świadectwem, dowodem zaufania. Utrata zaufania nauczyciela w stosunku do wychowanków prowadzi do porażki pedagogicznej wychowawcy. Daleki od optymistycznej wiary, że społeczeństwo jest idealne i jest godne zaufania w każdej sytuacji Korczak żąda szacunku dla przeszłości dziecka, dla jego niewiedzy, szacunku dla pracy poznania, szacunku dla własności ucznia i jego budżetu, szacunku dla bieżącej godziny, dla dnia dzisiejszego, dla jego tajemnic i tęsknot, szacunku dla każdej z osobna chwili ${ }^{40}$. Interakcje z tymi, których darzymy zaufaniem, są wolne od obaw, podejrzeń czy ostrożności i pozwalają na większą spontaniczność i otwartość. „Dlatego kluczową zasadą wychowania - stwierdza Józef Tischner - jest zasada wierności. Tutaj nie wolno zdradzać - nie wolno pod żadnym pozorem. [...] Dzięki pracy wychowawcy rodzi się w duszy człowieka jakaś prawda. Prawda ta staje się siłą człowieka. Wychowawca prawdy tej nie stwarza, jak położna nie stwarza dziecka. On tylko pomaga, dołączając do wysiłków człowieka swój wysiłek. Mimo to jego pomoc okazuje się często niezbędna - cenna, jak cenne jest ludzkie istnienie"41.

Darzenie innych osób zaufaniem pociąga za sobą pozytywne działania wobec tych osób - wyrażenie zaufania w działaniu. „Nauczyciele mogą jedynie wtedy spełnić zadania - podkreśla Wolfgang Brezinka - gdy zyskają szacunek i zaufanie uczniów. Zakłada to jednak, iż są godni szacunku i godni zaufania. Muszą więc wykazać się przymiotami, które uczynią możliwym, by w uczniach powstało to pozytywne nastawienie do nich. Nie chodzi tu jednak tylko o specjalne cnoty zawodowe, jak życzliwość, cierpliwość lub sprawiedliwość, lecz także

\footnotetext{
40 Por. Z. Jasiński, dz. cyt., s. 110-114.

41 J. Tischner, Etyka solidarności..., s. 88.
} 
o ogólne uzdolnienia i cnoty, które są cenione w społeczeństwie"42. Istnieją normy zobowiązujące do zaufania i normy zobowiązujące do zachowania się w sposób wiarygodny. Reguły zaufania na równi odnoszą się do tych, którzy obdarzają zaufaniem, jak i do tych, którzy są nim obdarzani. Zaufanie rodzi zaufanie, jest zaraźliwe. Prowadzi do wyłonienia się kultury zaufania. „Kultura zaufania zazwyczaj skłania do współpracy i wspólnego działania. [...] Jest jednak funkcjonalna tylko wtedy, gdy reguły mają charakter dwustronny, a więc zalecają - a co za tym idzie, wyzwalają - zaufanie, ale też zdecydowanie potępiają - a co za tym idzie, zapobiegają - nadużywaniu zaufania"43. Osoba jest więc określana z jednej strony przez własną aktywność, z drugiej zaś przez odpowiednie prowadzenie i oddziaływanie z zewnątrz. W tak rozumianym wychowaniu spotykają się ze sobą osoby, które wzajemnie obdarowują się swoim człowieczeństwem.

\section{Summary}

TRUST AS THE FOUNDATION FOR UNDERTAKING EDUCATIONAL ACTIVITIES

This article is an attempt to reflect on the value of trust in the dynamics of human existence and educational practice. According to the author, the pedagogy of creative co-existence stems from and at the same time builds an educational community. In pedagogical practice, it is important to develop a culture of trust and a personal dialogue, as well as to return to the masterpupil relationship.

Key w ord s: trust, educational practice, culture of trust

${ }^{42}$ W. Brezinka, Wychowywać dzisiaj. Zarys problematyki, Kraków 2007, s. $238-239$.

${ }^{43}$ P. Sztompka, Zaufanie..., s. 323. 
